\title{
Gene expression profiling revealed novel mechanism of action of Taxotere and Furtulon in prostate cancer cells Yiwei Li ${ }^{1}$, Maha Hussain ${ }^{2}$, Sarah H Sarkar ${ }^{1}$, James Eliason ${ }^{1}$, Ran $\mathrm{Li}^{1}$ and Fazlul H Sarkar*1
}

\author{
Address: ${ }^{1}$ Departments of Pathology and Internal Medicine, Karmanos Cancer Institute, Wayne State University School of Medicine, Detroit, MI, \\ USA and 2Division of Hematology/Oncology, Department of Internal Medicine, University of Michigan, Ann Arbor, MI, USA \\ Email: Yiwei Li - yiweili@med.wayne.edu; Maha Hussain - fsarkar@med.wayne.edu; Sarah H Sarkar - ssarkar@wayne.edu; \\ James Eliason - jeliason@med.wayne.edu; Ran Li - ranli6@hotmail.com; Fazlul H Sarkar* - fsarkar@med.wayne.edu \\ * Corresponding author
}

Published: 18 January 2005

BMC Cancer 2005, 5:7 doi:10.1186/147I-2407-5-7
Received: 30 September 2004

Accepted: 18 January 2005

This article is available from: http://www.biomedcentral.com/I47/-2407/5/7

(c) $2005 \mathrm{Li}$ et al; licensee BioMed Central Ltd.

This is an Open Access article distributed under the terms of the Creative Commons Attribution License (http://creativecommons.org/licenses/by/2.0), which permits unrestricted use, distribution, and reproduction in any medium, provided the original work is properly cited.

\begin{abstract}
Background: Both Taxotere and Capecitabine have shown anti-cancer activity against various cancers including prostate cancer. In combination, Taxotere plus Capecitabine has demonstrated higher anti-cancer activity in advanced breast cancers. However, the molecular mechanisms of action of Taxotere and Capecitabine have not been fully elucidated in prostate cancer.

Methods: The total RNA from PC 3 and LNCaP prostate cells untreated and treated with $2 \mathrm{nM}$ Taxotere, II0 $\mu$ M Furtulon (active metabolite of Capecitabine), or I nM Taxotere plus $50 \mu \mathrm{M}$ Furtulon for 6, 36, and 72 hours, was subjected to Affymetrix Human Genome UI33A Array analysis. Real-time PCR and Western Blot analysis were conducted to confirm microarray data.

Results: Taxotere and Furtulon down-regulated some genes critical for cell proliferation, cell cycle progression, transcription factor, cell signaling, and oncogenesis, and up-regulated some genes related to the induction of apoptosis, cell cycle arrest, and differentiation in both cell lines. Taxotere and Furtulon also up-regulated some genes responsible for chemotherapeutic resistance, suggesting the induction of cancer cell resistance to these agents.

Conclusions: Taxotere and Furtulon caused the alternation of a large number of genes, many of which may contribute to the molecular mechanisms by which Taxotere and Furtulon inhibit the growth of prostate cancer cells. This information could be utilized for further mechanistic research and for devising optimized therapeutic strategies against prostate cancer.
\end{abstract}

\section{Background}

Prostate cancer is the most common cancer and the second leading cause of cancer related deaths in men in the United States with an estimated 230,110 new cases and 29,500 deaths in 2004 [1]. Initial treatment for prostate cancer is usually androgen-ablative therapy, radiotherapy or radical prostatectomy and the patients respond to androgen-ablative therapy in the beginning of treatment. However, many patients eventually fail this therapy and die of recurrent androgen-independent prostate cancer and metastasis [2]. Up to $30 \%$ of men undergoing radical prostatectomy will also relapse, often as a result of micrometastatic cancer present at the time of surgery [3]. The efficacy of cytotoxic chemotherapy for treatment of 
hormone-refractory prostate cancer has been tested in clinical trials. In general, response rates of $<10 \%$ were observed in single-agent studies [2]. Thus, there is a tremendous need for the development of mechanism-based targeted strategies for treatment of prostate cancer.

Taxotere, a member of taxane family, is semi-synthesized from an inactive taxoid precursor extracted from the needles of the European yew, Taxus baccata. Its known basic mechanism of action is that it binds to tubulin and deranges the equilibrium between microtubule assembly and disassembly during mitosis [4]. Stabilization of microtubules by Taxotere impairs mitosis and exerts an anticancer effect in tumors [4]. Taxotere has shown clinical activity in wide spectrum of solid tumors including breast, lung, ovarian, prostate cancers, etc $[5,6]$. In metastatic breast, lung, and ovarian cancer, randomized trials have shown that Taxotere-containing therapies are superior to or as effective as established standard chemotherapeutic regimens and are often associated with an improved safety profile [6]. Clinical trials have also found that weekly Taxotere in patients with metastatic hormonerefractory prostate cancer is associated with improvements in clinical benefit response and quality of life $[7,8]$. Thus, Taxotere is currently considered to be among the most important anticancer drugs in cancer chemotherapy. In addition to its effects on microtubules, Taxotere also induces apoptosis with down-regulation of $\mathrm{bcl}_{\mathrm{XL}}$ and bcl2 , and upregulation of p21 $1^{\mathrm{WAF} 1}$ and p53 $[9,10]$. We have previously reported that Taxotere down-regulates some genes for cell proliferation, mitotic spindle formation, transcription factors, and oncogenesis, and up-regulates some genes related to induction of apoptosis and cell cycle arrest in prostate cancer cells, suggesting the pleiotropic effects of Taxotere on prostate cancer cells [11].

Capecitabine is an orally administered systemic prodrug of 5'-deoxy-5-fluorouridine (5-DFUR or Furtulon) which is converted to 5-fluorourasil (5-FU) [12]. Capecitabine is readily absorbed from the gastrointestinal tract. In human and animals, carboxylesterase hydrolyzes much of Capecitabine to 5'-deoxy-5-flurocytidine (5-DFCR). Cytidine deaminase, an enzyme found in most tissues including tumors, subsequently converts 5-DFCR to 5-DFUR. The enzyme, thymidine phosphorylase (dThdPase), then hydrolyzes 5-DFUR to the active drug 5-FU both in vivo and in vitro. After being converted to 5-FU, Capecitabine inhibits essential cellular biosynthetic processes and is incorporated into DNA to inhibit normal bioprocess function of the cell [13]. Capecitabine has shown antitumor activity in various cancers including prostate cancer [14-16]. 5-FU-based chemotherapy improves overall and disease-free survival of patients with cancer. However, response rates for 5-FU-based chemotherapy are low and a large number of tumors eventually becomes resistant to 5-FU $[13,17]$.

Clinical trials showed that chemotherapeutic combination with Taxotere and Capecitabine resulted in improved objective response rate and overall survival without a significant increase in the treatment related adverse effects in metastatic breast cancer and advanced non-small cell lung carcinoma $[18,19]$. However, the molecular mechanism(s) of action of Taxotere and Capecitabine have not been fully elucidated. In this study, we utilized highthroughput gene chip, which contains 22,215 known genes, to determine the alternation of gene expression profiles of hormone insensitive (PC3) and sensitive (LNCaP) prostate cancer cells exposed to Taxotere and Furtulon. The purpose of this study was: 1) to identify novel genes that have key roles in cancer cell killing and resistance induced by Taxotere and/or Furtulon; 2) to test whether similar genes are altered by Taxotere and Furtulon; 3 ) to test whether combination therapy alters genes that may reflect better treatment outcome or may provide information whether combination therapy could be antagonistic; 4) finally to provide molecular information for further mechanistic investigation and future clinical application.

\section{Methods \\ Cell culture and growth inhibition}

PC3 (ATCC, Manassas, VA) and LNCaP (ATCC) human prostate cancer cells were cultured in RPMI-1640 media (Invitrogen, Carlsbad, CA) supplemented with 10\% fetal bovine serum and $1 \%$ penicillin and streptomycin in a $5 \%$ $\mathrm{CO}_{2}$ atmosphere at $37^{\circ} \mathrm{C}$. Taxotere (Aventis Pharmaceuticals, Bridgewater, $\mathrm{NJ}$ ) was dissolved in DMSO to make 4 $\mu \mathrm{M}$ stock solution. Furtulon (Roche, Palo Alto, CA) was dissolved in PBS to make $100 \mathrm{mM}$ stock solution. For growth inhibition, PC3 and LNCaP cells were treated with Taxotere (1, 2, and $4 \mathrm{nM})$, Furtulon (50, 100, and 200 $\mu \mathrm{M})$, or $1 \mathrm{nM}$ Taxotere plus $50 \mu \mathrm{M}$ Furtulon for one to three days. Control PC3 and LNCaP cells received 0.01\% DMSO or $0.1 \%$ PBS for same time points. After treatment, PC3 and LNCaP cells were incubated with MTT $(0.5 \mathrm{mg} /$ $\mathrm{ml}$, Sigma, St. Louis, MO) at $37^{\circ} \mathrm{C}$ for two hours and then with isopropyl alcohol at room temperature for one hour. The spectrophotometric absorbance of the samples was determined by using ULTRA Multifunctional Microplate Reader (TECAN, Durham, NC) at $595 \mathrm{~nm}$. The concentrations of Taxotere and Furtulon used for our in vitro studies are easily achievable in humans, suggesting that our experimental results are relevant for human applications. The experiment was repeated three times and a $t$ test was performed to verify the significance of cell growth inhibition after treatment. 


\section{Microarray analysis for gene expression profiles}

PC3 and LNCaP cells were treated with 2 nM Taxotere, $110 \mu \mathrm{M}$ Furtulon, or $1 \mathrm{nM}$ Taxotere plus $50 \mu \mathrm{M}$ Furtulon for 6,36 , and $72 \mathrm{~h}$. Total RNA from each sample was isolated by Trizol (Invitrogen, Carlsbad, CA) and purified by RNeasy Mini Kit and RNase-free DNase Set (QIAGEN, Valencia, CA) according to the manufacturer's protocols. cDNA for each sample was synthesized by Superscript cDNA Synthesis Kit (Invitrogen, Carlsbad, CA) using the T7- $(\mathrm{dT})_{24}$ primer instead of the oligo(dT) provided in the kit. Then, the biotin-labeled cRNA was transcripted in vitro from cDNA by using BioArray HighYield RNA Transcript Labeling Kit (ENZO Biochem, New York, NY), and purified by RNeasy Mini Kit. The purified cRNA was fragmented by incubation in fragmentation buffer $(40 \mathrm{mM}$ Tris-acetate $\mathrm{pH} 8.1,100 \mathrm{mM}$ KOAc, $30 \mathrm{mM} \mathrm{MgOAc}$ ) at $95^{\circ} \mathrm{C}$ for $35 \mathrm{~min}$ and chilled on ice. The fragmented labeled cRNA was applied to Human Genome U133A Array (Affymetrix, Santa Clara, CA), which contains 22,215 human gene probes, and hybridized to the probes in the array. After washing and staining, the arrays were scanned. Two independent experiments were performed to verify the reproducibility of results.

\section{Microarray data normalization and analysis}

The gene expression levels of samples were normalized and analyzed by using Microarray Suite, MicroDB ${ }^{\mathrm{TM}}$, and Data Mining Tool software (Affymetrix, Santa Clara, CA). The absolute call (present, marginal, absent) and average difference of 22,215 gene expressions in a sample, and the absolute call difference, fold change, average difference of gene expressions between two or several samples were normalized and identified using these software. Statistical analysis of the mean expression average difference of genes, which show $>2$ fold change, was performed using a $t$ test between treated and untreated samples. Clustering and annotation of the gene expression were analyzed by using Cluster and TreeView [20], Onto-Express [21], and GenMAPP [22]. Genes that were not annotated or not easily classified were excluded from the functional clustering analysis.

\section{Real-time RT-PCR analysis for gene expression}

To verify the alterations of gene expression at the mRNA level, which appeared on the microarray, we chose representative genes (Table 1) with varying expression profiles for real-time RT-PCR analysis. Two micrograms of total RNA from each sample were subjected to reverse transcription using the Superscript first strand cDNA synthesis kit (Invitrogen, Carlsbad, CA) according to the manufacturer's protocol. Real-time PCR reactions were then carried out in a total of $25 \mu \mathrm{L}$ reaction mixture $(2 \mu \mathrm{l}$ of $\mathrm{CDNA}$, $12.5 \mu \mathrm{l}$ of 2 X SYBR Green PCR Master Mix, $1.5 \mu \mathrm{l}$ of each $5 \mu \mathrm{M}$ forward and reverse primers, and $7.5 \mu \mathrm{l}$ of $\mathrm{H}_{2} \mathrm{O}$ ) in SmartCycler II (Cepheid, Sunnyvale, CA). The PCR pro-
Table I: The primers used for real-time RT-PCR analysis

\begin{tabular}{|c|c|c|}
\hline Genes & Primer Sequence & PCR Product \\
\hline ATF5 & $\begin{array}{l}\text { ctc ctc ctt ctc cac ctc aa } \\
\text { gcc gac ttg ttc tgg tct ct }\end{array}$ & $103 \mathrm{bp}$ \\
\hline Cyclin A2 & $\begin{array}{l}\text { aat cag ttt ctt acc caa tac } \\
\text { ctg atg gca aat act tga }\end{array}$ & $127 \mathrm{bp}$ \\
\hline Fas/Apo-I & $\begin{array}{l}\text { caa aag tgt taa tgc cca agt } \\
\text { gca gtc tgg ttc atc cc }\end{array}$ & $187 \mathrm{bp}$ \\
\hline FOXMI & $\begin{array}{l}\text { gcc aca ctt agc gag acc c } \\
\text { atc aca agc att tcc gag aca }\end{array}$ & $189 \mathrm{bp}$ \\
\hline GADD45 & $\begin{array}{l}\text { cgc ctg tga gtg agt gc } \\
\text { ctt atc cat cct ttc ggt ctt }\end{array}$ & $154 \mathrm{bp}$ \\
\hline IGFBP2 & $\begin{array}{l}\text { atg ggc gag ggc act t } \\
\text { cag ctc ctt cat acc cga ctt }\end{array}$ & $189 \mathrm{bp}$ \\
\hline uPA & $\begin{array}{l}\text { ggg agc aga gac act aac gac } t \\
\text { ctc aca gcc cac aca aca ag }\end{array}$ & $108 \mathrm{bp}$ \\
\hline Ki-67 & $\begin{array}{l}\text { ccg ggc tcc atc atc } t \\
\text { ctc cag acg cca aaa taa gac }\end{array}$ & $148 \mathrm{bp}$ \\
\hline P2I WAFI & $\begin{array}{l}\text { ctg gag act ctc agg gtc gaa } \\
\text { gga tta ggg ctt cct ctt gga }\end{array}$ & $98 \mathrm{bp}$ \\
\hline P27KIPI & $\begin{array}{l}\text { cgc tcg cca gtc cat } t \\
\text { aca aaa ccg aac aaa aca aag }\end{array}$ & $187 \mathrm{bp}$ \\
\hline PIR & $\begin{array}{l}\text { cac tag ccc tcc atc ctc tac } \\
\text { ggg tct gcc aat gct tct }\end{array}$ & $151 \mathrm{bp}$ \\
\hline MMPI & $\begin{array}{l}\text { gct ttc ctc cac tgc tgc } t \\
\text { aac ttg cct ccc atc att ctt }\end{array}$ & $146 \mathrm{bp}$ \\
\hline STK6 & $\begin{array}{l}\text { tca gcg ggt ctt gtg t } \\
\text { ctc ttt tgg gtg tta ttc agt }\end{array}$ & $162 \mathrm{bp}$ \\
\hline Survivin & $\begin{array}{l}\text { cca ctg ccc cac tga gaa c } \\
\text { acc gga cga atg ctt ttt atg }\end{array}$ & $118 \mathrm{bp}$ \\
\hline TRIPI3 & $\begin{array}{l}\text { tct ggc agt gga caa gca gtt } \\
\text { tgg gag acg gct gtg tgg }\end{array}$ & $136 \mathrm{bp}$ \\
\hline GAPDH & $\begin{array}{l}\text { ctg cac cac caa ctg ctt ag } \\
\text { ttc agc tca ggg atg acc tt }\end{array}$ & $222 \mathrm{bp}$ \\
\hline$\beta$-actin & $\begin{array}{l}\text { cca cac tgt gcc cat cta cg } \\
\text { agg atc ttc atg agg tag tca gtc ag }\end{array}$ & $99 \mathrm{bp}$ \\
\hline
\end{tabular}

gram was initiated by $10 \mathrm{~min}$ at $95^{\circ} \mathrm{C}$ before 40 thermal cycles, each of $15 \mathrm{~s}$ at $95^{\circ} \mathrm{C}$ and $1 \mathrm{~min}$ at $60^{\circ} \mathrm{C}$. Data were analyzed according to the comparative $\mathrm{Ct}$ method and were normalized by actin expression in each sample. Melting curves for each PCR reaction were generated to ensure the purity of the amplification product.

\section{Western blot analysis}

We also conducted Western Blot analysis to verify the alterations of genes at the level of translation for selected genes with varying expression profiles. The PC3 and LNCaP cells were treated with 1 and $2 \mathrm{nM}$ Taxotere or 50 and $110 \mu \mathrm{M}$ Furtulon for 24, 48, and 72 hours. After treatment, the cells were lysed in $62.5 \mathrm{mM}$ Tris- $\mathrm{HCl}$ and $2 \%$ SDS, and protein concentration was measured using BCA protein assay (PIERCE, Rockford, IL). The proteins were subjected to $10 \%$ or $14 \%$ SDS-PAGE, and electrophoretically transferred to nitrocellulose membrane. The membranes were incubated with anti-cathepsin C (1:200, Santa Cruz, Santa Cruz, CA), anti-p16 (1:200, Santa Cruz, 
PC3 cells treated with Taxotere

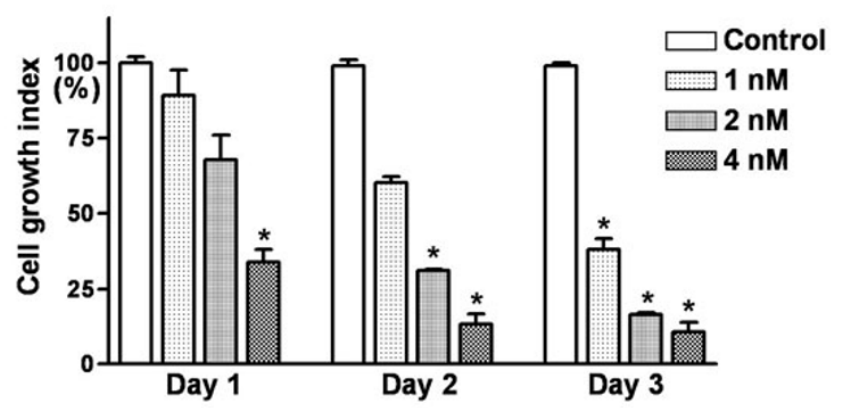

PC3 cells treated with Furtulon

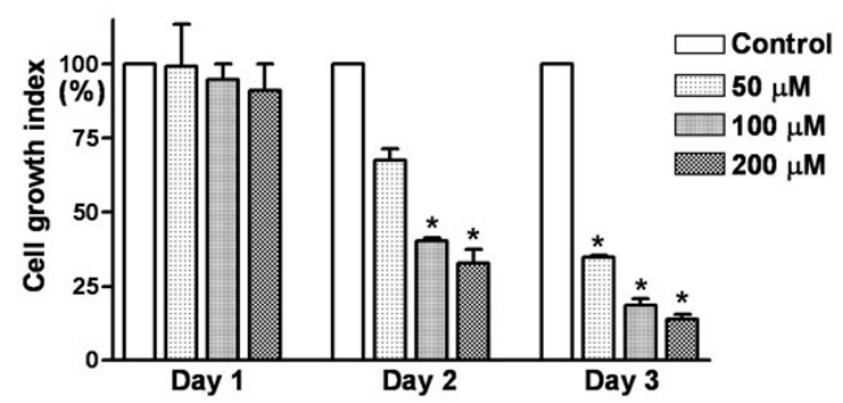

$\mathrm{PC} 3$ cells treated with $\mathrm{T}+\mathrm{F}$

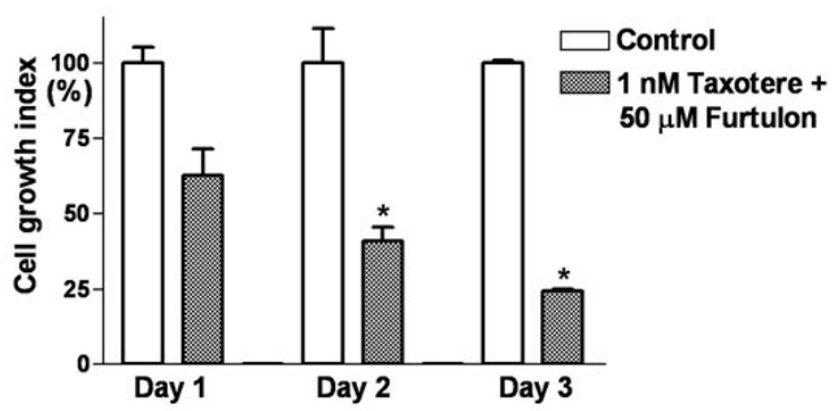

LNCaP cells treated with Taxotere

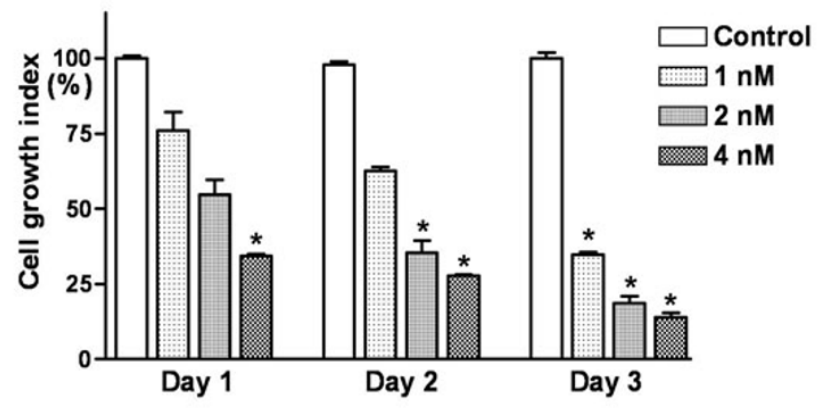

LNCaP cells treated with Furtulon

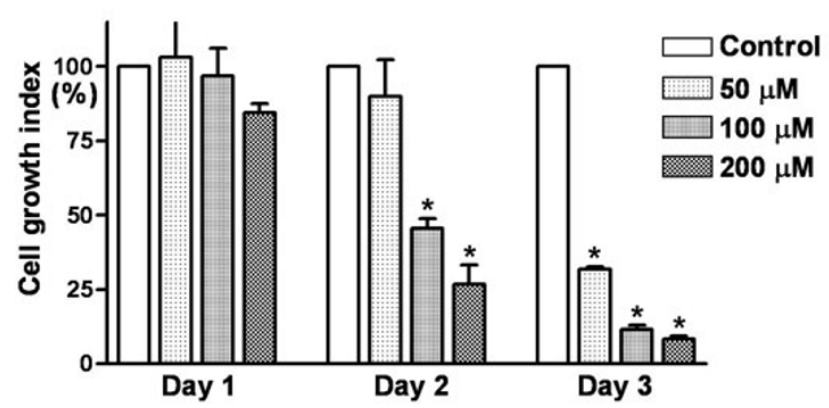

LNCaP cells treated with $T+F$

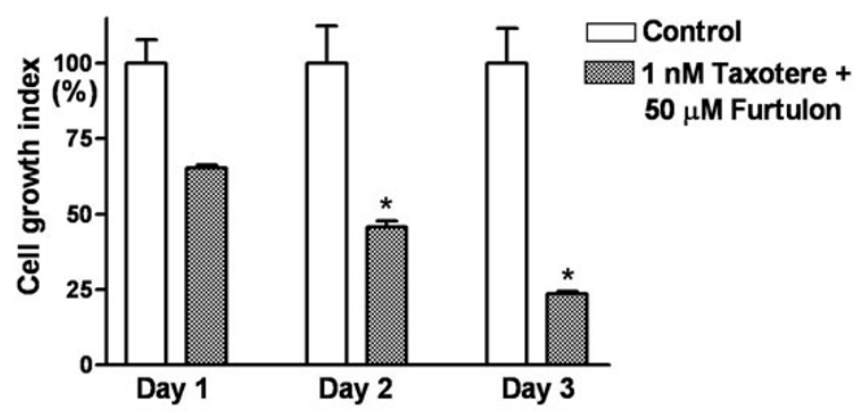

Figure I

Effects of Taxotere and/or Furtulon on the growth of PC3 and LNCaP Cells. PC3 and LNCaP prostate cancer cells treated with Taxotere and/or Furtulon resulted in a dose and time-dependent inhibition of cell proliferation $(*: p<0.05, n=3)$

Santa Cruz, CA), anti-IKK $\alpha$ (1:100, Santa Cruz, Santa Cruz, CA), anti-p21 WAF1 (1:500, Upstate, Lake Placid, NY), anti-Bax (1:10000, Trevigen, Gaithersburg, MD), anti-survivin (1:200, Alpha Diagnostic, San Antonio, TX), antiCDC2 (1:200, Santa Cruz, Santa Cruz, CA), anti-cyclin A (1:250, NeoMarkers, Union City, CA), anti-cyclin B
(1:200, Santa Cruz, Santa Cruz, CA), anti-cyclin E (1:250, NeoMarkers), and anti- $\beta$-actin (1:10000, Sigma, MO) primary antibodies, and subsequently incubated with secondary antibody conjugated with fluorescence dye. The signal was then detected and quantified by using Odyssey infrared imaging system (LI-COR, Lincoln, NE). 
Table 2: Fold change of genes in PC3 cells exposed to combination treatment or mono-treatment with Taxotere or Furtulon

\begin{tabular}{|c|c|c|c|c|c|c|c|c|c|}
\hline \multirow[t]{2}{*}{ Gene } & \multicolumn{3}{|c|}{ Taxotere } & \multicolumn{3}{|c|}{ Furtulon } & \multicolumn{3}{|c|}{ Taxotere+Furtulon } \\
\hline & $6 \mathrm{~h}$ & $36 \mathrm{~h}$ & $72 \mathrm{~h}$ & $6 \mathrm{~h}$ & $36 \mathrm{~h}$ & $72 \mathrm{~h}$ & $6 \mathrm{~h}$ & $36 \mathrm{~h}$ & $72 \mathrm{~h}$ \\
\hline \multicolumn{10}{|l|}{ Cell cycle and apoptosis } \\
\hline NM_00I237.I cyclin A2 (CCNA2) & NC & -1.1 & -2.0 & -1.1 & -1.7 & -3.0 & -1.1 & -1.4 & -2.5 \\
\hline BE4075 I 6 cyclin BI & -1.1 & -1.1 & -2.3 & NC & -3.0 & -6.1 & -1.1 & -3.0 & -5.3 \\
\hline NM_00I76I.I cyclin F (CCNF) & -1.3 & -1.3 & -2.5 & -1.5 & -2.5 & -2.6 & -1.6 & -1.6 & -2.5 \\
\hline NM_014303.I pescadillo homolog I & NC & -1.5 & -2.3 & 1.3 & -1.9 & -2.6 & -1.1 & -2.1 & -3.5 \\
\hline NM_003I32.I spermidine synthase (SRM) & NC & -1.5 & -2.5 & -1.1 & -1.3 & -2.5 & -1.1 & -1.1 & -2.3 \\
\hline NM_000389.I cyclin-dependent kinase inhibitor IA (p2I, CipI) & 1.7 & 1.0 & 2.6 & 1.9 & 2.6 & 3.5 & NC & 1.7 & 3.5 \\
\hline NM_003914.I cyclin AI (CCNAI) & 1.3 & 2.3 & 2.8 & NC & 1.5 & 2.5 & NC & NC & 2.0 \\
\hline L49506.I cyclin G2 & -2.1 & 2.0 & 2.6 & -2.8 & 2.3 & 2.3 & NC & 3.7 & 2.5 \\
\hline NM_004354.I cyclin G2 (CCNG2) & -1.9 & 3.0 & 3.2 & NC & 2.5 & 2.3 & 1.0 & 4.6 & 3.5 \\
\hline AL535380 B-cell translocation gene I, anti-proliferative & 1.1 & 1.7 & 3.5 & NC & 1.4 & 2.8 & -1.5 & 1.6 & 2.6 \\
\hline NM_006472.I upregulated by I,25-dihydroxyvitamin D-3 (VDUPI) & 1.3 & 2.1 & -2 & 1.0 & 2.1 & 2.3 & 1.0 & 2.3 & NC \\
\hline NM_015675.I growth arrest and DNA-damage-inducible, beta (GADD45B) & 1.2 & 2.5 & 6.5 & 1.6 & 1.5 & 2.6 & 1.0 & NC & 3.5 \\
\hline AF087853.I growth arrest and DNA damage inducible protein beta & NC & 2.0 & 4.6 & 1.3 & 1.2 & 2.3 & NC & NC & 3.2 \\
\hline AF078077.I growth arrest and DNA-damage-inducible protein GADD45beta & 1.5 & 2.0 & 5.3 & 1.1 & 1.2 & 2.1 & NC & 1.4 & 2.8 \\
\hline \multicolumn{10}{|l|}{ Transcription and translation } \\
\hline NM_007I I I.I transcription factor Dp-I (TFDPI) & NC & -1.6 & -3.2 & -1.3 & -1.1 & -2.0 & NC & -1.1 & -2.0 \\
\hline NM_0I 2068.2 activating transcription factor 5 (ATF5) & NC & -2.1 & -3.5 & NC & -1.5 & -2.1 & -1.3 & -1.1 & -2.6 \\
\hline NM_0I 225I.I transcription factor A, mitochondrial (TFAM) & 1.3 & -1.5 & -2.5 & NC & -1.6 & -2.0 & -1.1 & -2.0 & -3.7 \\
\hline AF220509.I transcription associated factor TAFII3 IL & NC & -2.3 & -3.2 & -1.3 & -1.3 & -2.3 & NC & -1.2 & -5.7 \\
\hline AA393940 eukaryotic translation initiation factor 5 A & -1.3 & -1.5 & -3.0 & -1.6 & -2.0 & -3.5 & -1.1 & -1.1 & -2.0 \\
\hline NM_001674.I activating transcription factor 3 (ATF3) & 1.4 & 1.9 & 14.9 & 1.5 & 2.1 & 3.5 & 1.1 & 2.6 & 4.9 \\
\hline \multicolumn{10}{|l|}{ Oncogenesis and other } \\
\hline NM_00I5II.I GROI oncogene (GROI) & 2 & -1.5 & -3.0 & 1.7 & 1.2 & -2.0 & NC & NC & -4.0 \\
\hline NM_002090.I GRO3 oncogene (GRO3) & 2.8 & -3.0 & -4.0 & 2.5 & -1.4 & -6.5 & NC & -2.8 & -13.9 \\
\hline NM_005754.I Ras-GTPase-activating protein SH3-domain-binding protein & NC & -1.7 & -2.8 & NC & -2.0 & -2.5 & NC & -2.6 & -4.6 \\
\hline NM_000026.I adenylosuccinate lyase (ADSL) & NC & -1.3 & -2.5 & NC & -1.4 & -2.6 & NC & -1.6 & -3.0 \\
\hline M8026I.I apurinic endonuclease (APE) & -1.1 & -1.4 & -3.0 & -1.1 & -1.9 & -2.6 & NC & -2.1 & -3.7 \\
\hline DI34|3.I tumor-associated I20 kDa nuclear protein pl20 & -1.1 & -2.0 & -3.2 & -1.7 & -1.7 & -2.5 & -2.3 & -1.1 & -3.0 \\
\hline Al743685 methionine aminopeptidase; elF-2-associated p67 & NC & -2.6 & -2.0 & 1.5 & -1.5 & -3.2 & NC & -2.3 & -2.8 \\
\hline NM_002634.2 prohibitin (PHB) & NC & -1.4 & -3.0 & NC & -1.9 & -2.1 & NC & -1.5 & -2.6 \\
\hline NM_002546.I osteoprotegerin & 1.5 & -1.3 & -3.0 & 1.2 & -2.1 & -3.0 & NC & -2.8 & -5.3 \\
\hline AF003934.I prostate differentiation factor mRNA & -1.5 & 4.3 & 26.0 & -1.7 & 4.9 & 16.0 & NC & 4.3 & 12.1 \\
\hline NM_000177.I gelsolin (amyloidosis, Finnish type) (GSN) & NC & 1.5 & 2.8 & NC & 2.0 & 3.5 & NC & 1.9 & 2.3 \\
\hline \multicolumn{10}{|l|}{ Invasion and metastasis } \\
\hline NM_003254.I tissue inhibitor of metalloproteinase I (TIMPI) & NC & 2.0 & 2.5 & NC & 2.6 & 3.7 & NC & 2.6 & 3.7 \\
\hline NM_003255.2 tissue inhibitor of metalloproteina(TIMP2) & NC & 1.6 & 2.5 & NC & 2.3 & 3.5 & NC & 1.6 & 3.5 \\
\hline NM_002638.I protease inhibitor 3 (PI3) & 1.2 & 2.0 & 2.0 & 1.1 & 3.7 & 5.7 & 1.0 & 3.0 & 4.6 \\
\hline NM_005562.I laminin, gamma 2 (nicein (I00 kD) & 1.3 & 1.5 & 2.0 & 1.1 & 2.5 & 3.7 & NC & 2.3 & 3.7 \\
\hline NM_001908.I cathepsin B (CTSB) & NC & 1.7 & 3.0 & NC & 1.7 & 2.8 & 1.1 & 1.3 & 2.5 \\
\hline NM_002658.I plasminogen activator, urokinase (PLAU) & NC & 2.3 & 3.5 & NC & 2.8 & 2.3 & 1.0 & 2.1 & 1.9 \\
\hline NM_000930.I plasminogen activator, tissue (PLAT) & 1.1 & 2.5 & 4.6 & NC & 5.7 & 9.8 & NC & 3.2 & 4.9 \\
\hline NM_00242I.2 matrix metalloproteinase I (MMPI) & NC & 1.4 & 4.3 & NC & 4.9 & 18.4 & NC & 5.7 & 13.0 \\
\hline NM_004994.I matrix metalloproteinase 9 (MMP9) & 1.1 & 1.7 & 2.0 & 1.0 & 1.9 & 2.0 & NC & 2.5 & 2.1 \\
\hline NM_000435.I Notch homolog 3 (NOTCH3) & NC & 2.0 & 2.6 & -2 & 2.3 & 3.2 & NC & 3.5 & 3.5 \\
\hline \multicolumn{10}{|l|}{ Resistance to chemotherapeutic agents } \\
\hline NM_000499.2 cytochrome P450, subfamily I (CYPIAI) & 1.4 & 3.0 & 4.0 & NC & 3.5 & 5.3 & 1.2 & 9.2 & 10.6 \\
\hline NM_006697.I cisplatin resistance associated (CRA) & 1.0 & 1.7 & 2.0 & -1.3 & 2.0 & 2.6 & NC & NC & 2.6 \\
\hline NM_005980.I SI00 calcium-binding protein P (SI00P) & -1.2 & 4.9 & 24.3 & 1.1 & 10.6 & 27.9 & NC & 6.5 & 19.7 \\
\hline NM_002961.2 S100 calcium-binding protein A4 (SI00A4) & 3.0 & 3.7 & 5.3 & 1.0 & 5.7 & 11.3 & 2.8 & 6.5 & 10.6 \\
\hline NM_020672.I S100-type calcium binding protein AI4 (LOC57402) & NC & 1.5 & 2.0 & NC & 2.1 & 2.6 & 1.1 & 1.6 & 2.1 \\
\hline NM_00 I894.I casein kinase I, epsilon (CSNKIE) & NC & 1.7 & 3.2 & NC & 2.0 & 2.6 & 1.1 & 1.7 & 3.2 \\
\hline NM_000700.I annexin AI (ANXAI) & NC & 1.9 & 2.3 & NC & 2.0 & 2.3 & NC & 1.6 & 2.1 \\
\hline
\end{tabular}

The genes in this list showed a $>2$ fold change in expression in at least one time point in both mono and combination treatment. NC: No change; Negative value: Decrease; Positive value: Increase. 
Table 3: Fold change of genes in LNCaP cells exposed to combination treatment or mono-treatment with Taxotere or Furtulon

\begin{tabular}{|c|c|c|c|c|c|c|c|c|c|}
\hline \multirow[t]{2}{*}{ Gene } & \multicolumn{3}{|c|}{ Taxotere } & \multicolumn{3}{|c|}{ Furtulon } & \multicolumn{3}{|c|}{ Taxotere+Furtulon } \\
\hline & $6 \mathrm{~h}$ & $36 \mathrm{~h}$ & $72 \mathrm{~h}$ & $6 \mathrm{~h}$ & $36 \mathrm{~h}$ & $72 \mathrm{~h}$ & $6 \mathrm{~h}$ & $36 \mathrm{~h}$ & $72 \mathrm{~h}$ \\
\hline \multicolumn{10}{|l|}{ Cell cycle and apoptosis } \\
\hline NM_00 I 786.I cell division cycle 2 (CDC2) & -1.2 & -7.5 & -12.1 & -1.1 & -2.8 & -1.6 & NC & -4.0 & -14.9 \\
\hline D88357.I mRNA for CDC2 delta $T$ & -1.1 & -6.1 & -14.9 & NC & -2.8 & -1.6 & -1.1 & -4.3 & -13.0 \\
\hline NM_00I237.I cyclin A2 (CCNA2) & -1.2 & -5.7 & -12.1 & NC & NC & -2.1 & -1.1 & -8.6 & -13.9 \\
\hline NM_004702.I cyclin E2 (CCNE2) & 1.6 & -5.3 & -3.2 & NC & -2.3 & -1.7 & -1.7 & -4.9 & -8.0 \\
\hline AFII 2857.I cyclin E2 splice variant I mRNA & 1.2 & -3.5 & -3.2 & NC & -2.0 & -1.6 & -1.4 & -7.0 & -8.6 \\
\hline NM_00I76I.I cyclin F (CCNF) & -1.5 & -2.5 & -3.7 & -1.1 & -1.1 & -2.0 & -1.4 & -2.3 & -2.8 \\
\hline ABO I 2305.I cyclin-dependent kinase 2 & -1.7 & -3.5 & -5.3 & -2.0 & -2.1 & -2.1 & NC & -2.8 & -3.5 \\
\hline U30872.I mitosin mRNA & -1.2 & -4.6 & -6.1 & NC & -2.1 & -1.3 & NC & -3.2 & -7.0 \\
\hline NM_000389.I cyclin-dependent kinase inhibitor IA (p2I, CipI) & 1.3 & 9.8 & 8.6 & 1.0 & 2.0 & 2.0 & 1.0 & 8.0 & 7.5 \\
\hline NM_006763.I BTG family, member 2 (BTG2) & 1.5 & 6.1 & 6.5 & 1.1 & 1.7 & 2.1 & 1.4 & 5.3 & 3.7 \\
\hline NM_006472.I upregulated by I,25-dihydroxyvitamin D-3 (VDUPI) & 1.0 & 3.5 & 3.5 & 1.0 & 1.5 & 2.6 & 1.0 & 2.3 & 3.0 \\
\hline NM_001924.2 growth arrest and DNA-damage-inducible, alpha & 1.4 & 7.5 & 7.5 & NC & 1.9 & 2.6 & 1.1 & 7.0 & 7.5 \\
\hline BC003637.I Similar to DNA-damage-inducible transcript 3 & 1.0 & 2.6 & 2.6 & 1.1 & 2.1 & 2.5 & NC & 2.6 & 2.8 \\
\hline NM_014454.I p53 regulated PA26 nuclear protein (PA26) & 1.1 & 4.0 & 3.0 & 1.1 & 1.4 & 2.6 & 1.1 & 3.7 & 3.7 \\
\hline NM_00470I.2 cyclin B2 (CCNB2) & -1.1 & -8 & -13.9 & NC & 1.3 & -1.3 & -1 & -4.9 & -19.7 \\
\hline NM_00I255.I CDC20 (cell division cycle 20) & -1.9 & -90.5 & -147 & NC & 1.6 & -1.9 & -1.6 & -13 & -157 \\
\hline NM_021873.I cell division cycle 25B (CDC25B) & -1.1 & -1.6 & -2.5 & NC & NC & -1.4 & -1 & -2.3 & -3.25 \\
\hline NM_001827.I CDC28 protein kinase 2 (CKS2) & -1.1 & -4.6 & -6.5 & NC & 1.6 & -1.6 & -1.2 & -3.5 & -5.7 \\
\hline NM_00I I68.I survivin (BIRC5) & -1.1 & -27.9 & -294 & NC & NC & -1.6 & NC & -6.9 & $-|8|$ \\
\hline \multicolumn{10}{|l|}{ Transcription, translation, oncogenesis, angiogenesis, other } \\
\hline NM_021953.I forkhead box MI (FOXMI) & -1.2 & -13.9 & -42.2 & -1.1 & -1.2 & -2.0 & NC & -2.8 & -45.3 \\
\hline NM_000465.I BRCAI associated RING domain I (BARDI) & -1.3 & -1.9 & -2.0 & NC & -1.1 & -2.1 & -1.2 & -2.6 & -4.9 \\
\hline NM_003368.I ubiquitin specific protease I (USPI) & NC & -2.6 & -1.6 & NC & -2.0 & -1.4 & NC & -2.1 & -1.9 \\
\hline NM_0067I6.I activator of S phase kinase (ASK) & -1.2 & -6.5 & -5.3 & -1.2 & -1.3 & -2.0 & -1.1 & -4.6 & -11.3 \\
\hline NM_003246.I thrombospondin I (THBSI) & NC & -2.0 & -3.5 & -1.9 & -1.4 & -2.6 & -1.1 & -1.6 & -4.6 \\
\hline NM_00I I47.I angiopoietin 2 (ANGPT2) & 3.5 & 3.5 & 8.0 & 1.7 & 5.3 & 8.0 & -0.5 & 4.9 & 2.8 \\
\hline AFI87858.I angiopoietin-2 isoform-I & NC & 2.6 & 4.3 & NC & 1.5 & 3.5 & NC & 2.0 & 2.0 \\
\hline NM_000435.I Notch (Drosophila) homolog 3 (NOTCH3) & 1.3 & 3.0 & 2.8 & 1.0 & 2.3 & 2.1 & NC & 2.1 & 3.0 \\
\hline NM_001674.I activating transcription factor 3 (ATF3) & NC & 1.5 & 2.5 & NC & 1.7 & 2.5 & NC & 2.6 & 4.3 \\
\hline NM_003I58.I serinethreonine kinase 6 (STK6) & -1.7 & -11.3 & -9.8 & 1.1 & 1.2 & -1.7 & -1.3 & -8.6 & -26 \\
\hline NM_003600.I serinethreonine kinase I5 (STKI5) & -1.2 & -3.7 & -8.6 & NC & NC & -1.6 & -1.3 & -4 & -6.1 \\
\hline AFI62704.I androgen receptor mRNA & NC & 1.3 & -1.6 & 1.2 & 1.3 & -2.1 & -1.1 & -1.6 & -2 \\
\hline \multicolumn{10}{|l|}{ Resistance to chemotherapeutic agents } \\
\hline NM_000693.I aldehyde dehydrogenase IA3 (ALDHIA3) & NC & 4.0 & 3.2 & 1.0 & 1.1 & 2.1 & 1.2 & 4.9 & 4.3 \\
\hline NM_005980.I SI00 calcium-binding protein P (SI00P) & 1.0 & 5.7 & 4.0 & 1.5 & 2.6 & 3.0 & NC & 2.6 & 2.6 \\
\hline
\end{tabular}

The genes in this list showed a $>2$ fold change in expression in at least one time point in both mono and combination treatment. NC: No change; Negative value: Decrease; Positive value: Increase.

\section{Results \\ Cell growth inhibition}

MTT assay showed that the treatment of PC3 and LNCaP prostate cancer cells with Taxotere, Furtulon, or lower concentration of Taxotere plus Furtulon resulted in dose and time-dependent inhibition of cell proliferation (Figure 1), demonstrating the inhibitory effect of Taxotere and Furtulon on the growth of PC3 and LNCaP prostate cancer cells.

\section{Regulation of mRNA expression by Taxotere and Furtulon treatment}

Microarray analysis showed that the alterations of gene expression were occurred as early as 6 hours of Taxotere and/or Furtulon treatment, and were more evident with longer treatment (Table 2 and 3 ).

Clustering analysis based on gene function showed downregulation of some genes for cell proliferation and cell cycle progression (cyclin A, cyclin F, CDC2, CDK2, etc), transcription factors (transcription factor A, ATF5, TAF1131L, FOXM1, etc), and oncogenesis (GRO onco- 
Table 4: Comparison of difference in gene expression between combination treatment and mono-treatment in PC3 cells

\begin{tabular}{|c|c|c|c|}
\hline \multirow[t]{2}{*}{ Gene } & \multicolumn{3}{|c|}{ Taxotere+Furtulon } \\
\hline & $6 \mathrm{~h}$ & $36 \mathrm{~h}$ & $72 \mathrm{~h}$ \\
\hline \multicolumn{4}{|c|}{ Decrease in combination treatment, No change or increase in mono-treatment. } \\
\hline NM_00I26I.I cyclin-dependent kinase 9 (CDC2-related kinase) (CDK9) & -1.3 & -1.2 & -2.3 \\
\hline NM_016507.I CDC2-related protein kinase 7 (CrkRS) & NC & -1.6 & -2.3 \\
\hline AF080 I57.I lkB kinase-a (IKK-alpha) & NC & -2.0 & -1.6 \\
\hline U62296.I transcription factor NF-YC & -1.1 & -1.7 & -2.3 \\
\hline BC005003.I nuclear transcription factor $Y$, gamma & -1.1 & -2.0 & -2.1 \\
\hline BC00I77I.I transcription factor IIF & NC & -1.6 & -2.3 \\
\hline Al434345 activating transcription factor I & NC & -2.5 & -2.6 \\
\hline BC00II73.I eukaryotic translation initiation factor 3 & NC & -1.3 & -2.0 \\
\hline U78525.I eukaryotic translation initiation factor (elF3) & NC & -1.4 & -2.0 \\
\hline NM_00I8I4.I cathepsin C (CTSC) & NC & -1.3 & -2.0 \\
\hline NM_003377.I vascular endothelial growth factor B (VEGFB) & -2.1 & NC & NC \\
\hline AF035620.I BRCAI-associated protein 2 (BRAP2) & -2.3 & NC & NC \\
\hline AF035620.I BRCAI-associated protein 2 (BRAP2) & -2.3 & -2.0 & -1.4 \\
\hline NM_005346.2 heat shock 70 kD protein IB (HSPAIB) & -1.1 & -2.1 & -1.1 \\
\hline BC000478.I heat shock $70 \mathrm{kD}$ protein $9 \mathrm{~B}$ & NC & -1.7 & -2.3 \\
\hline NM_0I4278.I heat shock protein (hsp I I 0 family) (APG-I) & -1.2 & -1.3 & -2.0 \\
\hline BC002526.I Similar to heat shock protein, II0 kDa & -1.1 & -1.4 & -2.1 \\
\hline \multicolumn{4}{|l|}{ Increase in combination treatment, No change or decrease in mono-treatment. } \\
\hline NM_000077.I cyclin-dependent kinase inhibitor 2A (p I6, inhibits CDK4) & NC & 1.7 & 2.1 \\
\hline NM_00|262.1 cyclin-dependent kinase inhibitor $2 \mathrm{C}$ ( $\mathrm{p} \mid 8$, inhibits CDK4) & NC & 2.1 & 2.0 \\
\hline J03202.I laminin B2 chain mRNA & NC & 1.3 & 2.0 \\
\hline BG 164365 microtubule-associated protein IB & NC & 2.3 & 2.0 \\
\hline NM_000594.I tumor necrosis factor, member 2 & NC & 2.5 & 1.6 \\
\hline NM_00I065.I tumor necrosis factor, member IA & NC & 2.0 & 1.9 \\
\hline $\mathrm{BC} 000 \mathrm{I} 25 . \mathrm{I}$ Similar to transforming growth factor, beta I & -1.2 & 1.9 & 2.1 \\
\hline NM_005649.I transcription factor I7 (TCFI7) & NC & I.I & 2.3 \\
\hline NM_005923.2 mitogen-activated protein kinase kinase kinase 5 (MAP3K5) & NC & 1.6 & 2.1 \\
\hline NM_005204.I mitogen-activated protein kinase kinase kinase 8 (MAP3K8) & NC & 2.3 & 4.3 \\
\hline NM_000785.I cytochrome P450, subfamily XXVIIB & NC & 2.1 & 1.5 \\
\hline NM_002960.I SI 00 calcium-binding protein A3 (SI00A3) & NC & 2.5 & 2.5 \\
\hline NM_002962.I SI 00 calcium-binding protein A5 & NC & 8.6 & 10.6 \\
\hline
\end{tabular}

NC: No change; Negative value: Decrease; Positive value: Increase.

The genes in this list showed a $>2$ fold change in expression in at least one time point in combination treatment.

gene, BRCA1 associated RING domain, tumor-associated nuclear protein p120, etc) in Taxotere and/or Furtulon treated prostate cancer cells (Table 2 and 3 ). In contrast, Taxotere and/or Furtulon up-regulated some genes that are related to the induction of apoptosis (GADD45A, GADD45B, etc), cell cycle arrest (p21 CIP1, VDUP1, BTG, etc), and tumor suppression (Table 2 and 3 ).

Combination treatment with Taxotere and Furtulon also altered expression of some genes (CDC27, CDK9, p18, $\mathrm{IKK} \alpha$, etc) that showed no change in mono-treatment (Table 4 and 5), suggesting the synergic effects of combination treatment on some genes.

Taxotere and Furtulon also up-regulated some genes (S100P, ALDH1A3, casein kinase, annexin, etc) responsible for chemotherapeutic resistance, suggesting the induction of cancer cell resistance to these agents (Table 2 and 3). Taxotere and Furtulon also showed differential effects on PC3 cells with alteration of metastasis-related genes and on LNCaP cells with down-regulation of survivin, cyclin B \& E, CDC2, CDC25, and specifically AR by Furtulon, suggesting their effects mediated by both AR-independent and dependent pathways (Table 2 and 3 ).

\section{Target verification by real-time RT-PCR and western blot} To verify the alterations of gene expression at the mRNA level, which appeared on the microarray, we chose representative genes with varying expression profiles for realtime RT-PCR and Western Blot analysis. The results of real-time RT-PCR for these selected genes were in direct agreement with the microarray data (Figure 2). The same 
Table 5: Comparison of difference in gene expression between combination treatment and mono-treatment in LNCaP cells

\begin{tabular}{|c|c|c|c|}
\hline \multirow[t]{2}{*}{ Gene } & \multicolumn{3}{|c|}{ Taxotere+Furtulon } \\
\hline & $6 \mathrm{~h}$ & $36 \mathrm{~h}$ & $72 \mathrm{~h}$ \\
\hline \multicolumn{4}{|c|}{ Decrease in combination treatment, No change or increase in mono-treatment. } \\
\hline NM_00 I256.I cell division cycle 27 (CDC27) & NC & -1.6 & -2.0 \\
\hline NM_001963.2 epidermal growth factor (beta-urogastrone) (EGF) & NC & -3.5 & -1.9 \\
\hline NM_004 I I3.2 fibroblast growth factor I2B (FGFI2B) & NC & -4.3 & -1.2 \\
\hline UI 3022 negative regulator of programmed cell death ICH-IS (Ich-I) & NC & -2.3 & -2.0 \\
\hline AF249273.I Bcl-2-associated transcription factor short form mRNA & NC & -1.7 & -2.3 \\
\hline NM_00107I.I thymidylate synthetase (TYMS) & NC & -1.4 & -2.6 \\
\hline AF005068.I breast and ovarian cancer susceptibility protein (BRCAI) & NC & -4.6 & -17.1 \\
\hline NM_01 2068.2 activating transcription factor 5 (ATF5) & NC & -2.0 & -2.8 \\
\hline NM_02 I809.I TGF(beta)-induced transcription factor 2 (TGIF2) & NC & -1.6 & -2.1 \\
\hline NM_00I4I2.I eukaryotic translation initiation factor IA (EIFIA) & NC & -1.2 & -2.3 \\
\hline NM_002758.I mitogen-activated protein kinase kinase 6 (MAP2K6) & NC & -1.7 & -2.1 \\
\hline \multicolumn{4}{|c|}{ Increase in combination treatment, No change or decrease in mono-treatment. } \\
\hline NM_006034.I p53-induced protein (PIGII) & NC & 6.1 & 7.5 \\
\hline NM_000227.I laminin, alpha 3 & NC & 1.7 & 2.0 \\
\hline NM_000094.I collagen, type VII, alpha I (COL7AI) & NC & 1.4 & 6.5 \\
\hline NM_016437.I tubulin, gamma 2 (TUBG2) & NC & 1.4 & 2.1 \\
\hline NM_000853.I glutathione S-transferase theta I (GSTTI) & NC & 2.0 & 2.1 \\
\hline
\end{tabular}

NC: No change; Negative value: Decrease; Positive value: Increase.

The genes in this list showed a $>2$ fold change in expression in at least one time point in combination treatment.

alternations of gene expression were observed by realtime RT-PCR analysis, although the fold change in the expression level was not exactly same between these two different analytical methods. The results of Western Blot analysis were also in direct agreement with the microarray and real-time RT-PCR data (Figure 3 and our earlier report [11]). These results support the findings obtained from microarray experiments.

\section{Discussion}

It has been known that Taxotere binds to microtubules while Capecitabine is incorporated into DNA, inhibiting the bioprocess in cancer cells [4,13]. However, the precise molecular mechanisms for inhibiting cancer cell growth by Taxotere and/or Capecitabine have not been fully elucidated. From gene expression profiles of Taxotere and/or Capecitabine treated prostate cancer cells, we found that these chemotherapeutic agents caused alterations in the expression of many genes related to the control of cell proliferation, apoptosis, transcription, translation, cell signaling, oncogenesis, and angiogenesis (Figure 4), although the cellular target of Taxotere or Capecitabine appears to be different.

It has been well known that CDCs regulate the molecules related to the cell cycle initiation and progression and that cyclins associate with cyclin-dependent protein kinases
(CDKs) and CDCs to control the process of cell cycle $[23,24]$. The CDK inhibitors including p $21^{\text {WAF1 }}, \mathrm{p} 16^{\mathrm{INK} 4 \mathrm{~A}}$, and $\mathrm{p} 18^{\mathrm{INK} 4 \mathrm{C}}$ have been demonstrated to arrest the cell cycle and inhibit the growth of cancer cells $[23,24]$. Our results showed that Cyclins (cyclin A2, cyclin E2, cyclin F, cyclin B1), CDK2, CDC2, and other cell growth promotion genes (pescadillo, spermidine synthase, mitotin) [2527] were down-regulated in Taxotere and/or Furtulon treated prostate cancer cells, while CDK inhibitor p21 WAF1 and other growth inhibitor genes (BTG2, VDUP1, antiproliferative B-cell translocation gene 1 ) $[28,29]$ were upregulated, suggesting that Taxotere and/or Furtulon inhibited the growth of prostate cancer cells through the arrest of cell cycle and the inhibition of cell proliferation (Figure 4). The down-regulation of CDC27, CDK9, EGF, and FGF12B, and up-regulation of $\mathrm{p} 16^{\mathrm{INK} 4 \mathrm{~A}}$ and $\mathrm{p} 18^{\mathrm{INK} 4 \mathrm{C}}$ were also observed in combination treatment but not in monotreatment, suggesting the synergic effect of combination treatment. These observations are novel in Taxotere and/ or Furtulon treated prostate cancer cells.

Induction of apoptosis by chemotherapeutic agents also leads to the inhibition of cancer cell growth. It has been reported that Taxotere is able to induce apoptosis by caspase-3 dependent or independent cell death mechanism [30]. Capecitabine may induce apoptosis through Fas/ FasL or Bax/Bcl-2 pathway [31,32]. From gene expression 
PC3 GADD45

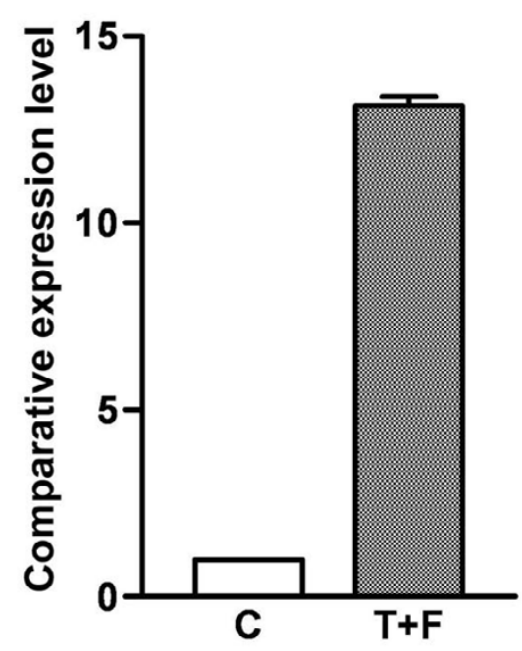

LNCaP cyclin A2

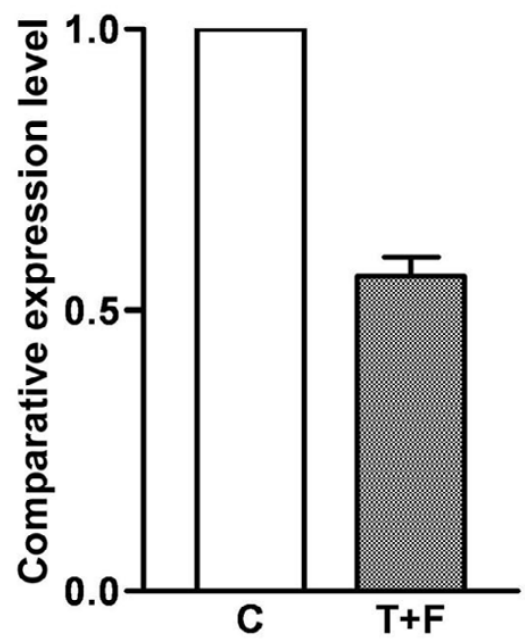

PC3 ATF5

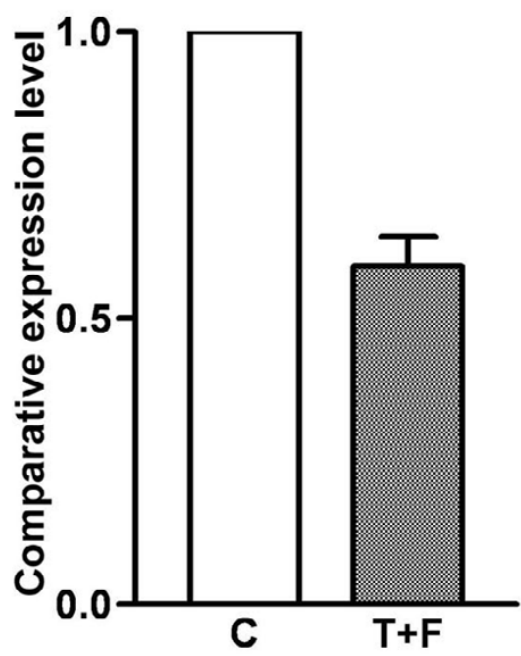

LNCaP FOXM1

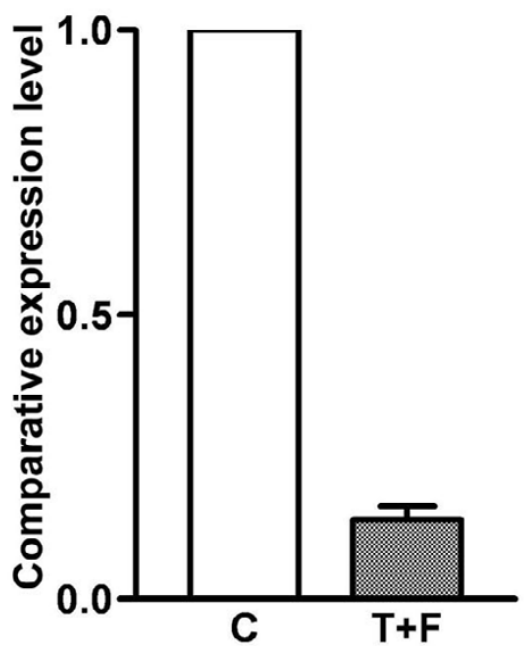

LNCaP survivin

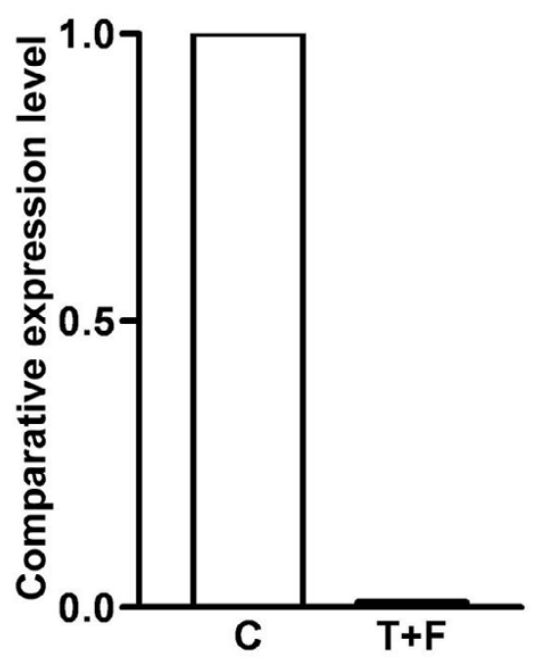

LNCaP p21 WAF1

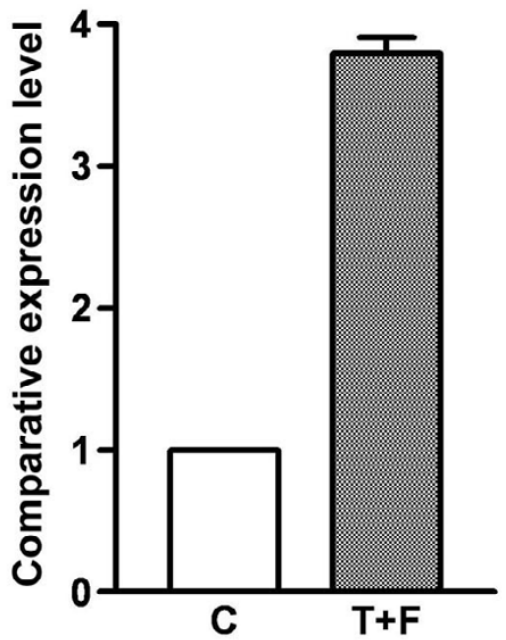

Figure 2

Real-time RT-PCR showing the altered expression of specific genes in Taxotere and Furtulon treated PC3 and LNCaP cells. (C: control; T+F: Taxotere and Furtulon combination treatment.)

profile, we found that Taxotere and/or Furtulon increased level of growth arrest and DNA-damage-inducible alpha (GADD45A), GADD45B, p53 regulated PA26 nuclear protein (PA26), and p53-induced protein 11 (PIG11), all of which are related to the induction of apoptotic processes. GADD45A and GADD45B have been known to promote apoptosis and regulate G2/M arrest [33]. PA26 is a target of the p53 tumor suppressor and a member of the GADD family with the properties of inducing apoptosis
[34]. PIG11 as a downstream target of p53 is also involved in the apoptotic processes [35]. The combination treatment also showed down-regulation of negative regulator of programmed cell death ICH-1S and Bcl-2-associated transcription factor, which was not occurred in monotreatment. The induction of apoptosis mediated by GADD45A, GADD45B, PA25, and PIG11 could be another molecular mechanism by which Taxotere and/or Furtulon inhibit the growth of prostate cancer cells. 

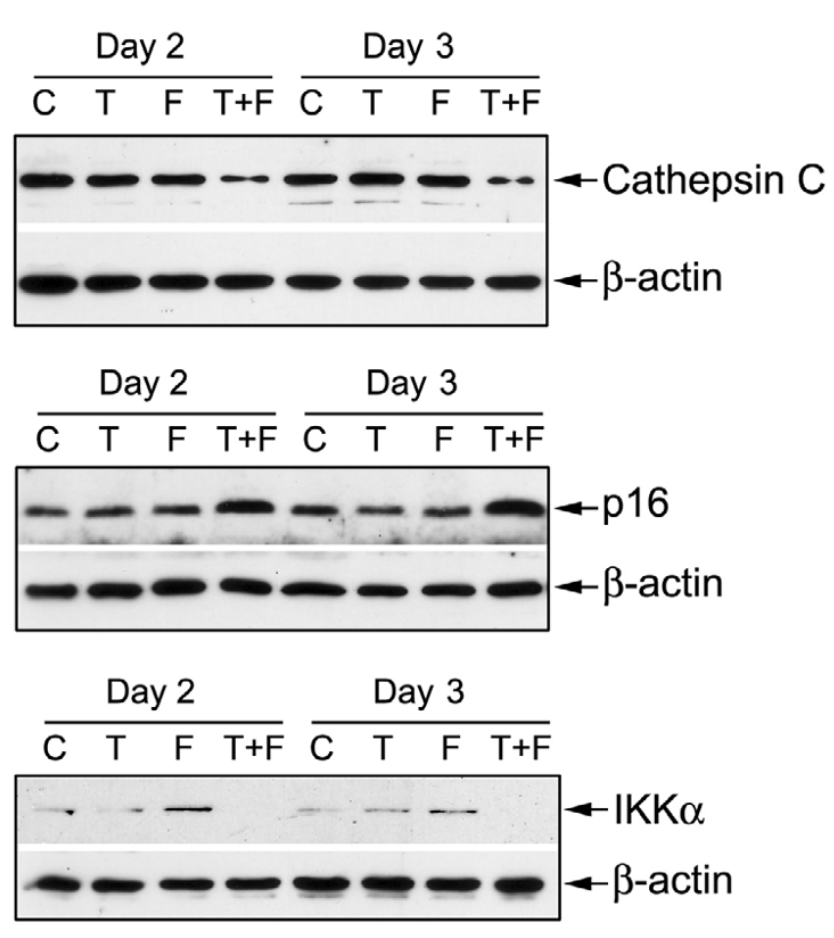

\section{Figure 3}

Western Blot analysis showing the altered expression of specific genes in Taxotere and Furtulon treated PC-3 or LNCaP cells. (C: control; T: Taxotere treatment; F: Furtulon treatment; T+F: Taxotere and Furtulon combination treatment.)

We also found that Taxotere and/or Furtulon inhibited the expression of transcription factors (FOXM1, ATF5, TFAM, TAFII31L), translation factors (EIF1A, EIF5A), oncogene (GRO1, GRO3, BRCA1-associated protein, tumor-associated nuclear protein p120), and heat shock protein, and up-regulated the genes for differentiation (prostate differentiation factor). These results are novel, and suggest the beneficial effects of Taxotere and/or Furtulon on the inhibition of cancer cell growth and oncogenesis.

It is important to note that Taxotere and/or Furtulon also up-regulated the expression of some genes which are known to induce cell resistance to chemotherapeutic agents and to favor cell survival. Among these genes, calcium-binding protein S100P has been found to be highly expressed in cells which develop acquired resistance to anti-tumor agents [36]. The overexpression of aldehyde dehydrogenase 1 (ALDH1) has also been detected solely in classical multidrug resistance cancer cells $[37,38]$. It has been reported that Annexin-I, casein kinase 1, and cispla- tin-resistance associated protein expressions modulate drug resistance in tumor cells $[39,40]$. The up-regulation of these molecules by Taxotere and/or Furtulon could induce cell resistance to chemotherapeutic agents. Also, Taxotere and/or Furtulon were found to up-regulate the expression of Notch 3, angiopoietin, activating transcription factor 3, which could favor cell survival [41-43]. Further in depth mechanistic studies are needed to address these issues. The investigation on overcoming these unbeneficial effects with other agents must be devised, which is ongoing in our laboratory.

Taxotere showed no effect on AR expression while Furtulon down-regulated AR expression in LNCaP cells, suggesting that the combination could be superior in ARpositive cells. The genes altered by Taxotere and/or Furtulon with respect to the control of cell growth, apoptosis, transcription, oncogenesis, and metastasis in androgen insensitive PC3 cells are different from that in androgen sensitive LNCaP cells, suggesting that the effects of Taxotere and Furtulon may be mediated by both ARdependent and independent signaling pathways. We observed up-regulation of tissue inhibitor of metalloproteinase 1 (TIMP1), TIMP2, and protease inhibitor 3 in Taxotere and/or Furtulon treated PC3 cells, suggesting that Taxotere and/or Furtulon may exert anti-metastatic effect. However, we also observed increase in the expression of MMP1, MMP9, cathepsin B, UPA, and tPA in Taxotere and Furtulon treated PC3 cells, therefore, more experimental studies are needed to reveal the overall effect of Taxotere and Furtulon on metastatic processes. These results were not observed in androgen sensitive LNCaP cells, suggesting difference in effects that could be mediated through different cell signal transduction pathways.

\section{Conclusions}

In conclusion, Taxotere and/or Furtulon directly and indirectly caused changes in the expression of many genes that are critically involved in the control of cell proliferation, apoptosis, transcription, translation, oncogenesis, angiogenesis, metastasis, and drug resistance (Figure 4). These findings could provide molecular information for further investigation on the mechanisms by which Taxotere and Furtulon exerts their pleiotropic effects on prostate cancer cells. These results could also be important in devising mechanism-based targeted therapeutic strategies for prostate cancer, especially in devising combination therapy for drug resistant prostate cancers. However, further in-depth investigations are needed in order to establish cause and effect relationships between these altered genes and therapeutic response in prostate cancer cells.

\section{Competing interests}

The author(s) declare that they have no competing interests. 
A.

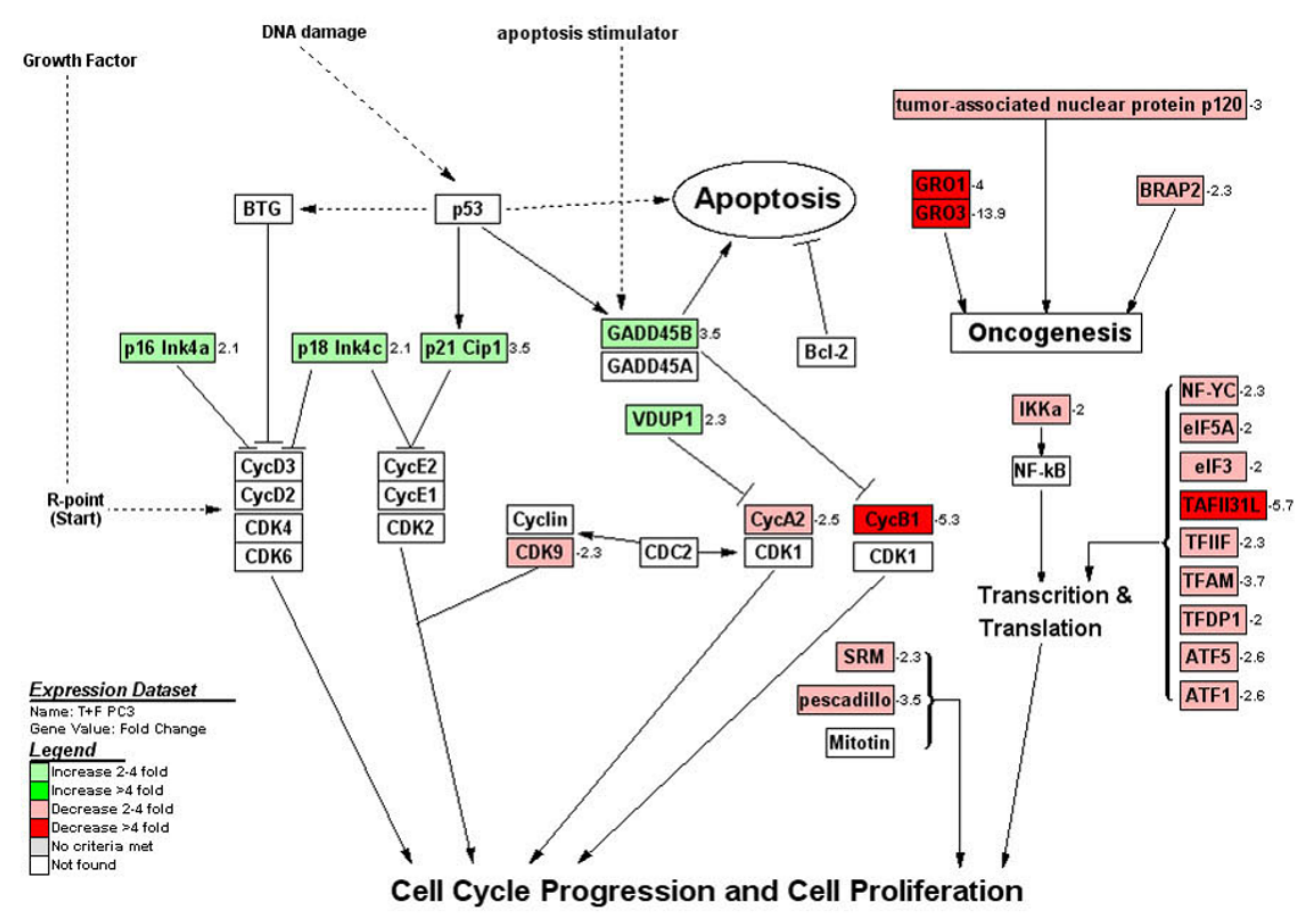

B.

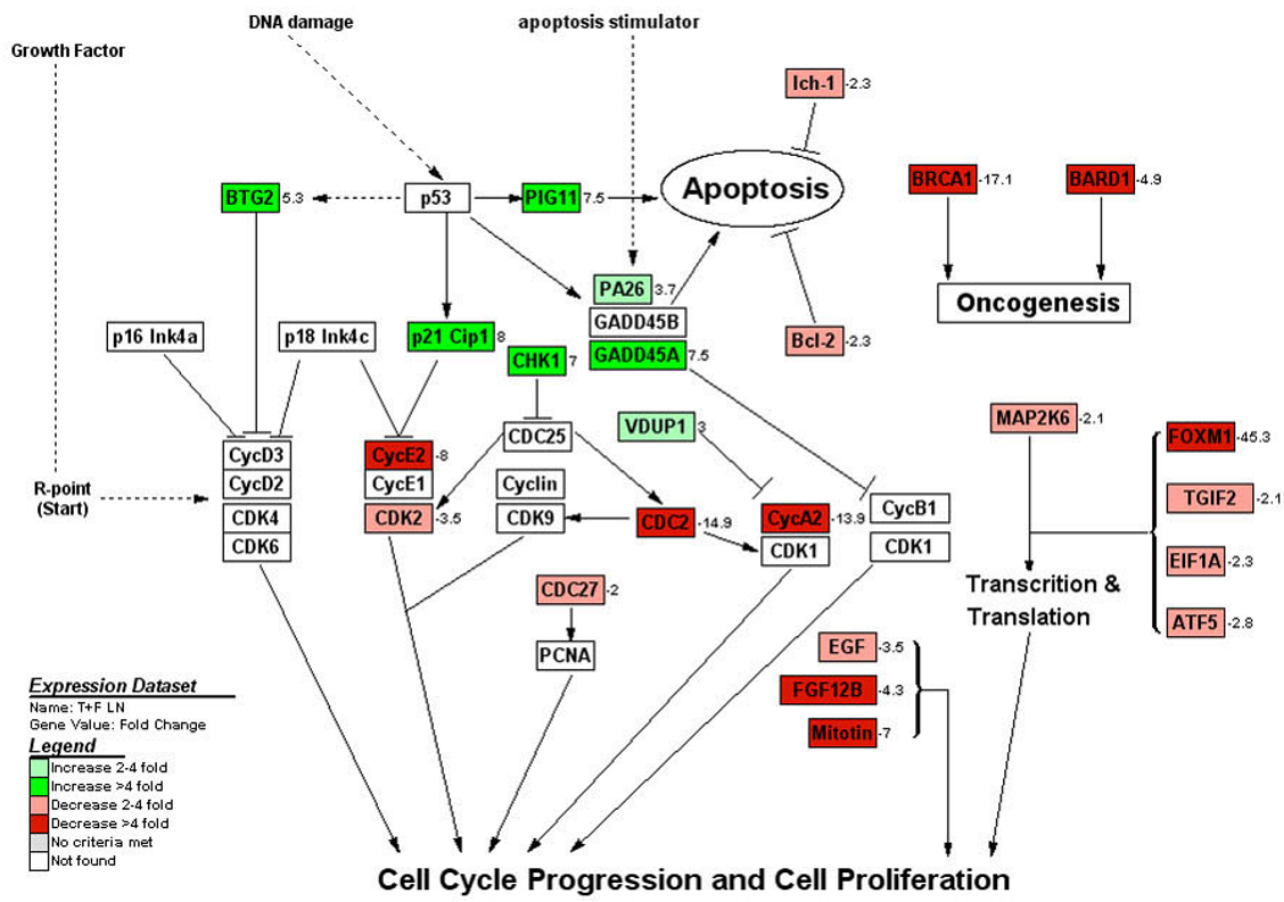

\section{Figure 4}

Effects of Taxotere and Furtulon on cell cycle, apoptosis, and other pathway related gene expression analyzed and visualized by GenMAPP software integrated with cDNA microarray data. A: PC3 cells. B: LNCaP cells. (positive value: increase in fold change; negative value: decrease in fold change; A: PC3 cells; B: LNCaP cells) 


\section{Authors' contributions}

FHS designed the study and prepared the manuscript. YL carried out cell growth inhibition, microarray and Western Blot analysis and drafted the manuscript. MH participated in the design of the study. RL and SHS carried out real-time PCR. JE prepared Furtulon reagent. All authors read and approved the manuscript.

\section{Acknowledgements}

This work was partly funded by a grant from Aventis Pharmaceuticals (awarded to F.H.S.).

\section{References}

I. American Cancer Society: Cancer Facts \& Figures 2004. In Cancer Facts \& Figures 2004 Inc American Cancer Society, Inc; 2004:4-6.

2. Denmeade SR, Isaacs JT: A history of prostate cancer treatment. Nat Rev Cancer 2002, 2:389-396.

3. Gopalkrishnan RV, Kang DC, Fisher PB: Molecular markers and determinants of prostate cancer metastasis. J Cell Physiol 200I, I 89:245-256.

4. Fulton B, Spencer CM: Docetaxel. A review of its pharmacodynamic and pharmacokinetic properties and therapeutic efficacy in the management of metastatic breast cancer. Drugs 1996, 5 I: 1075-1092.

5. Beer TM, El Geneidi M, Eilers KM: Docetaxel (taxotere) in the treatment of prostate cancer. Expert Rev Anticancer Ther 2003, 3:26I-268.

6. Hong WK: The current status of docetaxel in solid tumors. An M. D. Anderson Cancer Center Review. Oncology (Huntingt) 2002, I 6:9-15

7. Petrioli R, Pozzessere D, Messinese S, Sabatino M, Di Palma T, Marsili S, Correale P, Manganelli A, Salvestrini F, Francini G: Weekly lowdose docetaxel in advanced hormone-resistant prostate cancer patients previously exposed to chemotherapy. Oncology 2003, 64:300-305.

8. Gravis G, Bladou F, Salem N, Macquart-Moulin G, Serment G, Camerlo J, Genre D, Bardou VJ, Maraninchi D, Viens P: Weekly administration of docetaxel for symptomatic metastatic hormone-refractory prostate carcinoma. Cancer 2003, 98:1627-1634

9. Avramis VI, Nandy P, Kwock R, Solorzano MM, Mukherjee SK, Danenberg $P$, Cohen LJ: Increased p2 I/WAF-I and p53 protein levels following sequential three drug combination regimen of Fludarabine, cytarabine and docetaxel induces apoptosis in human leukemia cells. Anticancer Research 1998, 18:2327-2338.

10. Stein CA: Mechanisms of action of taxanes in prostate cancer. Semin Oncol 1999, 26:3-7.

II. Li Y, Li X, Hussain M, Sarkar FH: Regulation of microtubule, apoptosis, and cell cycle-related genes by taxotere in prostate cancer cells analyzed by microarray. Neoplasia 2004, 6:158-167.

12. Ishikawa T, Utoh M, Sawada N, Nishida M, Fukase Y, Sekiguchi F, Ishitsuka $\mathrm{H}$ : Tumor selective delivery of $\mathbf{5}$-fluorouracil by capecitabine, a new oral fluoropyrimidine carbamate, in human cancer xenografts. Biochem Pharmacol 1998, 55:109|-1097.

13. Longley DB, Harkin DP, Johnston PG: 5-fluorouracil: mechanisms of action and clinical strategies. Nat Rev Cancer 2003, 3:330-338.

14. Kondo Y, Terashima M, Sato A, Taguchi T: A Pilot Phase II Study of Capecitabine in Advanced or Recurrent Colorectal Cancer.Jpn J Clin Oncol 2004, 34: I95-20I.

15. Rischin D, Phillips KA, Friedlander M, Harnett P, Quinn M, Richardson G, Martin A: A phase II trial of capecitabine in heavily pretreated platinum-resistant ovarian cancer. Gynecol Oncol 2004, 93:417-42I.

16. Morant R, Bernhard J, Dietrich D, Gillessen S, Bonomo M, Borner M, Bauer J, Cerny T, Rochlitz C, Wernli M, Gschwend A, Hanselmann S, Hering F, Schmid HP: Capecitabine in hormone-resistant metastatic prostatic carcinoma - a phase II trial. Br J Cancer 2004, 90:1312-1317.

17. Johnston PG, Kaye S: Capecitabine: a novel agent for the treatment of solid tumors. Anticancer Drugs 200I, I 2:639-646.
18. Han JY, Lee DH, Kim HY, Hong EK, Yoon SM, Chun JH, Lee HG, Lee SY, Shin EH, Lee JS: A phase II study of weekly docetaxel plus capecitabine for patients with advanced nonsmall cell lung carcinoma. Cancer 2003, 98:1918-1924.

19. McDonald F, Miles D: Xeloda and Taxotere: a review of the development of the combination for use in metastatic breast cancer. Int J Clin Pract 2003, 57:530-534.

20. Eisen MB, Spellman PT, Brown PO, Botstein D: Cluster analysis and display of genome-wide expression patterns. Proc Nat Acad Sci U S A 1998, 95: |4863-|4868.

21. Khatri P, Draghici S, Ostermeier GC, Krawetz SA: Profiling gene expression using onto-express. Genomics 2002, 79:266-270.

22. Dahlquist KD, Salomonis N, Vranizan K, Lawlor SC, Conklin BR: GenMAPP, a new tool for viewing and analyzing microarray data on biological pathways. Nat Genet 2002, 3 I : 19-20.

23. Coffman JA: Cell cycle development. Dev Cell 2004, 6:321-327.

24. Swanton C: Cell-cycle targeted therapies. Lancet Oncol 2004, 5:27-36.

25. Kinoshita Y, Jarell AD, Flaman JM, Foltz G, Schuster J, Sopher BL, Irvin DK, Kanning K, Kornblum HI, Nelson PS, Hieter P, Morrison RS: Pescadillo, a novel cell cycle regulatory protein abnormally expressed in malignant cells. J Biol Chem 200I, 276:6656-6665.

26. He Y, Shimogori T, Kashiwagi K, Shirahata A, Igarashi K: Inhibition of cell growth by combination of alpha-difluoromethylornithine and an inhibitor of spermine synthase. J Biochem (Tokyo) 1995, I | 7:824-829.

27. Todorov IT, Philipova RN, Joswig G, Werner D, Ramaekers FC: Detection of the I 25-kDa nuclear protein mitotin in centrosomes, the poles of the mitotic spindle, and the midbody. Exp Cell Res 1992, I 99:398-40I.

28. Chen JG, Yang CP, Cammer M, Horwitz SB: Gene expression and mitotic exit induced by microtubule-stabilizing drugs. Cancer Res 2003, 63:7891-7899.

29. Han $\mathrm{SH}$, Jeon JH, Ju HR, Jung U, Kim KY, Yoo HS, Lee $Y H$, Song KS, Hwang HM, Na YS, Yang Y, Lee KN, Choi I: VDUPI upregulated by TGF-betal and I,25-dihydorxyvitamin D3 inhibits tumor cell growth by blocking cell-cycle progression. Oncogene 2003, 22:4035-4046.

30. Kolfschoten GM, Hulscher TM, Duyndam MC, Pinedo HM, Boven E: Variation in the kinetics of caspase-3 activation, $\mathrm{Bcl}-2$ phosphorylation and apoptotic morphology in unselected human ovarian cancer cell lines as a response to docetaxel. Biochem Pharmacol 2002, 63:733-743.

31. Ciccolini J, Fina F, Bezulier K, Giacometti S, Roussel M, Evrard A, Cuq P, Romain S, Martin PM, Aubert C: Transmission of apoptosis in human colorectal tumor cells exposed to capecitabine, Xeloda, is mediated via Fas. Mol Cancer Ther 2002, I:923-927.

32. Suzuki K, Kazui T, Yoshida M, Uno T, Kobayashi T, Kimura T, Yoshida $\mathrm{T}$, Sugimura $\mathrm{H}$ : Drug-induced apoptosis and p53, BCL-2 and BAX expression in breast cancer tissues in vivo and in fibroblast cells in vitro. Jpn J Clin Oncol 1999, 29:323-33I.

33. Yin F, Bruemmer D, Blaschke F, Hsueh WA, Law RE, Herle AJ: Signaling pathways involved in induction of GADD45 gene expression and apoptosis by troglitazone in human MCF-7 breast carcinoma cells. Oncogene 2004, 23:46|4-4623.

34. Velasco-Miguel S, Buckbinder L, Jean P, Gelbert L, Talbott R, Laidlaw J, Seizinger B, Kley N: PA26, a novel target of the p53 tumor suppressor and member of the GADD family of DNA damage and growth arrest inducible genes. Oncogene 1999, 18:127-137.

35. Liang XQ, Cao EH, Zhang Y, Qin JF: P53-induced gene I I (PIG I I) involved in arsenic trioxide-induced apoptosis in human gastric cancer MGC-803 cells. Oncol Rep 2003, I 0: I 265-I269.

36. Bertram J, Palfner K, Hiddemann W, Kneba M: Elevated expression of SIOOP, CAPL and MAGE 3 in doxorubicin-resistant cell lines: comparison of mRNA differential display reverse transcription-polymerase chain reaction and subtractive suppressive hybridization for the analysis of differential gene expression. Anticancer Drugs 1998, 9:31 1-317.

37. Ludwig $A$, Dietel $M$, Lage $H$ : Identification of differentially expressed genes in classical and atypical multidrug-resistant gastric carcinoma cells. Anticancer Res 2002, 22:3213-3221.

38. Sladek NE, Kollander R, Sreerama L, Kiang DT: Cellular levels of aldehyde dehydrogenases (ALDHIAI and ALDH3AI) as predictors of therapeutic responses to cyclophosphamidebased chemotherapy of breast cancer: a retrospective study. 
Rational individualization of oxazaphosphorine-based cancer chemotherapeutic regimens. Cancer Chemother Pharmacol 2002, 49:309-32I.

39. Grunicke H, Hofmann J, Utz I, Uberall F: Role of protein kinases in antitumor drug resistance. Ann Hematol 1994, 69 SuppI I:SI-S6.

40. Wang Y, Serfass L, Roy MO, Wong J, Bonneau AM, Georges E: Annexin-I expression modulates drug resistance in tumor cells. Biochem Biophys Res Commun 2004, 3 I 4:565-570.

4I. Peng L, Sun J, Wang WD, Jian ZX, Ou JR: Biological effect of ectopic expression of angiopoietin-I and -2 in hepatocellular carcinoma cell line. Hepatobiliary Pancreat Dis Int 2003, 2:94-97.

42. Maillard I, Pear WS: Notch and cancer: best to avoid the ups and downs. Cancer Cell 2003, 3:203-205.

43. Allenspach EJ, Maillard I, Aster JC, Pear WS: Notch signaling in cancer. Cancer Biol Ther 2002, 1:466-476.

\section{Pre-publication history}

The pre-publication history for this paper can be accessed here:

http://www.biomedcentral.com/1471-2407/5/7/prepub

Publish with Biomed Central and every scientist can read your work free of charge

"BioMed Central will be the most significant development for disseminating the results of biomedical research in our lifetime. "

Sir Paul Nurse, Cancer Research UK

Your research papers will be:

- available free of charge to the entire biomedical community

- peer reviewed and published immediately upon acceptance

- cited in PubMed and archived on PubMed Central

- yours - you keep the copyright

Submit your manuscript here:

http://www.biomedcentral.com/info/publishing_adv.asp 